\title{
Tactics of Impression Management: Relative Success on Workplace Relationship
}

\author{
Dr Rajeshwari Gwal ${ }^{1}$
}

\section{ABSTRACT:}

Impression Management, the process by which people control the impressions others form of them, plays an important role in inter-personal behavior. All kinds of organizations consist of individuals with variety of personal characteristics; therefore those are important to manage them effectively. Identifying the behavior manner of each of these personal characteristics, interactions among them and interpersonal relations are on the basis of the impressions given and taken. Understanding one of the important determinants of individual's social relations helps to get a broader insight of human beings. Employees try to sculpture their relationships in organizational settings as well. Impression management turns out to be a continuous activity among newcomers, used in order to be accepted by the organization, and among those who have matured with the organization, used in order to be influential (Demir, 2002).

Keywords: Impression Management, Self Promotion, Ingratiation, Exemplification, Intimidation,

\section{Supplication}

\section{INTRODUCTION:}

When two individuals or parties meet, both form a judgment about each other. Impression Management theorists believe that it is a primary human motive; both inside and outside the organization (Provis,2010) to avoid being evaluated negatively (Jain,2012). Goffman (1959) initially started with the study of impression management by introducing a framework describing the way one presents them and how others might perceive that presentation (Cole, Rozelle, 2011). The first party consciously chooses a behavior to present to the second party in anticipation of a desired effect. Assuming the second party responds in the way that the first party intended, the first party will continue to use the particular strategy.

\footnotetext{
${ }^{1}$ Assistant Professor, Acropolis Faculty of Management \& Research, *No.1 Emerging B-School of Central India [AICTE-CII Survey,2014]* Acropolis North Campus, Indore [MP]
} 


\section{Tactics of Impression Management: Relative Success on Workplace Relationship}

\section{Impression Management}

Most people are concerned with making good first impressions on others, because they believe that these impressions will exert lasting effects. Hence during social interactions; individuals attempt to control their images both consciously and unconsciously (Schlenker,1980, p.V).This is called as Impression Management. It is a behavior used to create and maintain desired images of the self (Gardner \& Martinko, 1988).In other words, Impression Management is a process through which individuals attempt to influence the impressions other people form of them.

The desire to make a favorable impression on others is a strong one, so most of us do our best to "look good" to others when we meet them for the first time. Persons who perform impression management successfully do often gain important advantages in many situations (Sharp \& Getz, 1996; Wayne \& Liden, 1995).Individuals use different techniques for boosting their image which generally fall into two categories viz: effort increase their appeal to others (selfenhancement) and efforts to make the target person feel good in various ways (otherenhancement).Self- enhancement make use of specific strategies to bend the truth and enhance one's own appeal whereas in Other-enhancement tactics used play an important role in generating liking for the person responsible for them (Byrne,1992).

According to (Taylor, 1997), Impression Formation is an important universal trend for all individuals and managing these impressions affects one's life deeply (Sallot,2002). There is a need for those for organizational settings to understand the basic elements or constructs involved in impression management (Crane, \& Crane, 2004).Newcomers continuously use Impression management tactics to be accepted by the organization, whereas those who have matured with the organization, used in order to be influential (Demir, 2002). Impression management strategies has a lot to do with the protection and maintenance of power and has an impact on organization's culture and performance (Jones \& Pittman,1982).

Jones \& Pittman offered five strategies of impression management: Self-Promotion, Ingratiation, Exemplification, Intimidation and Supplication. Use of a particular strategy depends on what attribution the first party is seeking from the second party. Also these strategies can be used independently of one another (Jones \& Pittman,1982). This would mean the first party can use one or any number of the strategies to influence the second party feelings and perceptions of the situation.

\section{OBJECTIVES OF STUDY}

1) To identify the common tactic used by the employee for managing impression

2) To identify a particular behavior that all employees actually engage in for impression management

\section{RESEARCH METHODOLOGY}

Impression management tactics were measured by a scale taken from Bolino and Turnley (1999), based on the classification system proposed by Jones and Pittman (1982). Using Bolino Turnley 
(1999) Impression Management Scale the respondents answered statements by thinking about "how often you behave this way" The taxonomy in questionnaire includes: Self-Promotion, whereby individuals point out their abilities or accomplishments in order to be seen as competent by observers; Ingratiation, whereby individuals do favors or use flattery to elicit an attribution of likability from observers; Exemplification, whereby people self-sacrifice or go above and beyond the call of duty in order to gain the attribution of dedication from observers; Intimidation, where people signal their power or potential to punish in order to be seen as dangerous by observers; and Supplication, where individuals advertise their weaknesses or shortcomings in order to elicit an attribution of being needy from observers.

The study is Exploratory in nature. Sampling technique used is Convenience Sampling. 50 Academicians from various Academic Institutes of Indore were selected as the Respondents. Questionnaire were given to 50 respondents.8 questionnaires were not received and 7 were found to be incomplete. Respondents were supposed to fill two parts in the questionnaire. In the first part questions about the demographic characteristics of employees; in the other part questions designed to measure impression management were asked. A total of 35 questionnaires were selected for the analysis of Impression Management tactics. Respondents selected were Doctorates and Post Graduates with MBA, M.Sc, M.E, M.Tech, MCM and MCA with designations as Assistant Professor, Associate Professor and Professor.

\section{DATA ANALYSIS \& FINDINGS}

Table 1:

\begin{tabular}{|c|c|c|c|c|c|c|}
\hline STATEMENTS & $\begin{array}{l}\text { ME } \\
\text { AN }\end{array}$ & $\begin{array}{l}\text { AVERA } \\
\text { GE }\end{array}$ & $\begin{array}{l}\text { MAXI } \\
\text { MUM }\end{array}$ & $\begin{array}{l}\text { MINIM } \\
\text { UM }\end{array}$ & $\begin{array}{c}\text { ITE } \\
\text { M } \\
\text { ME } \\
\text { AN }\end{array}$ & $\begin{array}{c}\text { CONSTR } \\
\text { UCT } \\
\text { MEAN }\end{array}$ \\
\hline \multicolumn{7}{|l|}{ SELF-PROMOTION } \\
\hline $\begin{array}{l}\text { Talk proudly about your experience or } \\
\text { education. }\end{array}$ & 80 & \multirow{4}{*}{87} & \multirow{4}{*}{103} & \multirow{4}{*}{80} & $\begin{array}{c}2.28 \\
6\end{array}$ & \multirow{4}{*}{2.486} \\
\hline $\begin{array}{l}\text { Make people aware of your talents or } \\
\text { qualifications. }\end{array}$ & 83 & & & & $\begin{array}{c}2.37 \\
1\end{array}$ & \\
\hline $\begin{array}{l}\text { Let others know that you are valuable to the } \\
\text { organization. }\end{array}$ & 103 & & & & $\begin{array}{c}2.94 \\
3\end{array}$ & \\
\hline $\begin{array}{lrll}\text { Make people aware of your } \\
\text { accomplishments. }\end{array}$ & 82 & & & & $\begin{array}{c}2.34 \\
3\end{array}$ & \\
\hline \multicolumn{7}{|l|}{ INGRATIATION } \\
\hline $\begin{array}{l}\text { Compliment your colleagues so they will see } \\
\text { you as likable. }\end{array}$ & 90 & \multirow[t]{2}{*}{90.75} & \multirow[t]{2}{*}{110} & \multirow[t]{2}{*}{76} & $\begin{array}{c}2.57 \\
1\end{array}$ & \multirow[t]{2}{*}{2.592} \\
\hline $\begin{array}{l}\text { Take an interest in your colleagues' personal } \\
\text { lives to show them that you are friendly. }\end{array}$ & 76 & & & & $\begin{array}{c}2.17 \\
1\end{array}$ & \\
\hline
\end{tabular}




\begin{tabular}{|c|c|c|c|c|c|c|}
\hline $\begin{array}{l}\text { Praise your colleagues for their } \\
\text { accomplishments so they will consider you a } \\
\text { nice person. } \\
\text { Do personal favors for your colleagues to } \\
\text { show them that you are friendly. }\end{array}$ & 110 & & & & $\begin{array}{c}2.48 \\
6 \\
\end{array}$ & \\
\hline EXEMPLIFICATION & & & & & & \\
\hline $\begin{array}{l}\text { Stay at work late so people will know you } \\
\text { are hard working. }\end{array}$ & 58 & \multirow{4}{*}{54.25} & \multirow{4}{*}{62} & \multirow{4}{*}{44} & $\begin{array}{c}1.65 \\
7\end{array}$ & \multirow{4}{*}{1.550} \\
\hline $\begin{array}{l}\text { Try to appear busy, even at times when } \\
\text { things are slower. }\end{array}$ & 53 & & & & $\begin{array}{c}1.51 \\
4\end{array}$ & \\
\hline Arrive at work early to look dedicated. & 62 & & & & $\begin{array}{c}1.77 \\
1\end{array}$ & \\
\hline $\begin{array}{l}\text { Come to the office at night or on weekends } \\
\text { to show that you are dedicated. }\end{array}$ & 44 & & & & $\begin{array}{c}1.25 \\
7\end{array}$ & \\
\hline \multicolumn{7}{|l|}{ INTIMIDATION } \\
\hline $\begin{array}{l}\text { Be intimidating with coworkers when it will } \\
\text { help you get your job done. }\end{array}$ & 66 & \multirow{5}{*}{62.2} & \multirow{5}{*}{74} & \multirow{5}{*}{43} & $\begin{array}{c}1.88 \\
6\end{array}$ & \multirow{5}{*}{1.777} \\
\hline $\begin{array}{l}\text { Let others know you can make things } \\
\text { difficult for them if they push you too far. }\end{array}$ & 43 & & & & $\begin{array}{c}1.22 \\
9\end{array}$ & \\
\hline $\begin{array}{l}\text { Deal forcefully with colleagues when they } \\
\text { hamper your ability to get your job done. }\end{array}$ & 63 & & & & $\begin{array}{c}1.80 \\
0\end{array}$ & \\
\hline $\begin{array}{l}\text { Deal strongly or aggressively with coworkers } \\
\text { who interfere in your business. }\end{array}$ & 65 & & & & $\begin{array}{c}1.85 \\
7\end{array}$ & \\
\hline $\begin{array}{l}\text { Use intimidation to get colleagues to behave } \\
\text { appropriately. }\end{array}$ & 74 & & & & $\begin{array}{c}2.11 \\
4\end{array}$ & \\
\hline \multicolumn{7}{|l|}{ SUPPLICATION } \\
\hline $\begin{array}{l}\text { Act like you know less than you do so people } \\
\text { will help you out. }\end{array}$ & 73 & \multirow{5}{*}{65.4} & \multirow{5}{*}{74} & \multirow{5}{*}{58} & $\begin{array}{c}2.08 \\
6\end{array}$ & \multirow{5}{*}{1.868} \\
\hline $\begin{array}{l}\text { Try to gain assistance or sympathy from } \\
\text { people by appearing needy in some areas. }\end{array}$ & 61 & & & & $\begin{array}{c}1.74 \\
3 \\
\end{array}$ & \\
\hline $\begin{array}{l}\text { Pretend not to understand something to gain } \\
\text { someone's help. }\end{array}$ & 58 & & & & $\begin{array}{c}1.65 \\
7\end{array}$ & \\
\hline $\begin{array}{l}\text { Act like you need assistance so people will } \\
\text { help you out. }\end{array}$ & 74 & & & & $\begin{array}{c}2.11 \\
4\end{array}$ & \\
\hline $\begin{array}{l}\text { Pretend to know less than you do so you can } \\
\text { avoid an unpleasant assignment. }\end{array}$ & 61 & & & & $\begin{array}{c}1.74 \\
3\end{array}$ & \\
\hline
\end{tabular}


Tactics of Impression Management: Relative Success on Workplace Relationship

Table 2: Common Tactic and Particular Behavior of Academicians

\begin{tabular}{|l|c|l|}
\hline \multicolumn{1}{|c|}{$\begin{array}{c}\text { Impression } \\
\text { Management Tactics }\end{array}$} & Rank Order & \multicolumn{1}{|c|}{ Common Behavior } \\
\hline Self-Promotion & 2 & $\begin{array}{l}\text { Let others know that you are valuable to the } \\
\text { organization. }\end{array}$ \\
\hline Ingratiation & 1 & $\begin{array}{l}\text { Praise your colleagues for their accomplishments so } \\
\text { they will consider you a nice person }\end{array}$ \\
\hline Exemplification & 5 & Arrive at work early to look dedicated. \\
\hline Intimidation & 4 & $\begin{array}{l}\text { Use intimidation to get colleagues to behave } \\
\text { appropriately. }\end{array}$ \\
\hline Supplication & 3 & $\begin{array}{l}\text { Act like you need assistance so people will help you } \\
\text { out. }\end{array}$ \\
\hline
\end{tabular}

\section{SELF-PROMOTION}

Self-promotion is most often used when the chance of their claims being challenged or discredited is low (Rosenfeld et al., 1995, p.51). The table shows the highest value for Self promotion as 2.943 for the item- "Let others know that you are valuable to the organization".

Here maximum respondents self-promote them to achieve an attribution of confidence. They use the self descriptive communication to be seen as competent. The goal when using this strategy is usually an immediate one such as getting admitted into a university or a new job (Tedeschi \& Riess, 1981, p.11). Self-promotion is a proactive process in which the self-promoter has to actively say things to show the competence or at least undertake actions so that the competence is displayed to the target. Self-promotion is most often used when the chance of their claims being challenged or discredited is low (Rosenfeld et al., 1995, p.51). Next to this it was also found that the occurrence of self-promotion increases when individuals have the opportunity to openly impress someone with a higher status about their competence (Giacalone \& Rosenfeld, 1986).

\section{INGRATIATION}

Item Construct have mean values as Self enhancement (2.571), Other enhancement (2.171), Opinion conformity (3.143) and Favour doing (2.486)

By using ingratiation the respondents are concerned about influencing the targets liking for him/her. As seen from the table Opinion conformity (Praise your colleagues for their accomplishments so they will consider you a nice person.) has the highest value as 3.143.

Opinion conformity is also encouraged in situations where there are power differences. In an organizational setting the more difference there is in the power between two people the more likely it is that the lower one will imitate behaviors and values of the higher one (Rosenfeld et al., 1995). From the research presented it can be said that opinion conformity is an effective strategy to increase the attractiveness of an individual in the eyes of the more important target. 


\section{EXEMPLIFICATION}

The mean value obtained is 1.771 against the item- "Arrive at work early to look dedicated" as seen in the above table. Here Exemplifiers are those respondents who arrive at work early to look dedicated. They also avoid to take holidays. These individuals are willing to suffer to help others but in reality also attempt to make others feel guilty because they are not acting in a same morally and integer manner. The target can reduce their feelings of guilt by at least supporting the cause of the exemplifier (Jones \& Pittman, 1982). This tactic can actually also involve strategic self sacrifice (Rosenfeld et al., 1995). Furthermore the exemplifier often wants other people to know how hard he/she has been working, because they need to advertise their behavior (Rosenfeld et al., 1995)

\section{INTIMIDATION}

Item 5 in the questionnaire-"Intimidation to get colleagues to behave properly" got the highest score of 2.114. Intimidation is an impression management strategy designed to increase the credibility of one's threats and in turn enhance the probability that the target will comply with the actors' demands for agreement (Tedeschi \& Riess, 1981, p.11). Using Intimidation; the respondents' tries to convince his target that he is dangerous (Jones \& Pittman, 1982) and generally flow from high level to low level and usually a form of downward influence (Rosenfeld et al., 1995)

\section{SUPPLICATION}

For asking something earnestly and humbly, most of the respondents score the highest value 2.114 for the item- "Act like you know less than you do so people will help you out".

Supplication is used by individuals who are not able to use any of the strategies presented previously, as it involves exploiting ones weaknesses. The individual emphasizes his own dependence and weakness to obtain help from a more powerful other. By advertising their lack of ability, they attempt to activate a powerful social rule the norm of social responsibility that says you should help those who are in need (Rosenfeld et al., 1995, p.56). One heavy cost attached to using supplication is the costs of one's self-esteem in admitting one's incompetence.

\section{CONCLUSION}

The most common tactic used for Impression Management is Ingratiation .Employees attempt to make themselves likeable or more attractive to their colleagues by appreciating their accomplishments and achievements. But if this is done in excess, it may also result in disliking instead of creating a liking for self. Obvious ingratiation are detectable so it is always advisable to act with modesty and make self-demeaning statements on the unimportant issues while acting in a self-enhancing manner on the core matters (Schlenker, 1980). In this manner you can even things out and make ingratiation more credible. 


\section{Tactics of Impression Management: Relative Success on Workplace Relationship}

Next most common tactic used is Self-promotion. Employees who claim about their competencies will be highlighted only when the observer is competent himself. In case of an incompetent observer it will be tinted that these employees using Self-promotion have something to cover-up or make-up for. A good strategy for the self-promoter can be to organize that others will make claims on his/her behalf. Women who behave forcefully and boldly and in a positive manner are not evaluated as positively as men who engage in the same behavior (Rudman, 1998). Findings of their research put forth that women pay the price for this counter stereotypical behavior, even if it is essential for a flourishing career. It is not like they lack the ability to promote themselves but they daily have to choose regarding how to present themselves; whether in a feminine manner or a professional one (Rudman, 1998)

Employees using the tactic of supplication are perceived as lazy and demanding. As mentioned earlier in this chapter with this tactic the danger lies in its overuse (Rosenfeld et al., 1995). This tactic emphasizes employees dependence and weakness to obtain help from a more powerful other. By advertising their lack of ability, they attempt to activate a powerful social rule the norm of social responsibility that says you should help those who are in need (Rosenfeld et al., 1995, p.56). If an employee overuse or use it ineffectively, they can backfire and produce negative rather than positive reactions from others.

Using Intimidation technique may result in negative relationship and disliking and in some cases receive favorable performance evaluations out of fear.

Lastly employees using Supplication tactic may lose his self-esteem by admitting one's incompetencies in a particular task or field. Such employees are perceived as incompetent by other colleagues. If a colleague evaluates another colleague unfavorably it is also expected that this individual will be evaluated more negatively as to how much he/she is liked.

While tactics of Impression Management often succeed this is not always the case, and sometimes, they can boomerang, adversely affecting reactions to the people using them. That we try to make a favorable impression on others in many situations is obvious; and this makes a great deal of sense in attempting to gain membership in a fraternity. We all engage in positive self-presentation in a relatively automatic and effortless manner in well practiced scripts. These impressions are important and exert lasting effects on workplace relationships. Hence it is important to make a good impression on others when we care about their evaluations on us.

\section{REFERENCES:}

1. Bolino, M. C., \& Turnley, W. H. (1999). Measuring Impression Management in Organizations: A Scale Development Based on the Jones and Pittman Taxonomy. Organizational Research Methods, 2(2), 187.

2. Cole, Amy Y., Elizabeth J. Rozelle (2011), Emotional Intelligence And Impression Management: A Theoretical Framework, Insights Journal, Volume 2011, Issue 1, pp.93114. 


\section{Tactics of Impression Management: Relative Success on Workplace Relationship}

3. Crane \& Crane, E.(2004), Usage and Effectiveness of Impression Management Strategies in Organizational Settings, Journal of Group Psychotherapy Psychodrama and Sociometry.

4. Demir, K.(2002), Türkiye'deki Resmi ve Özel Lise Öğretmenlerinin İzlenim Yönetimi,Yayınlanmamış Doktora Tezi, Ankara Üniversitesi Eğitim Bilimleri Enstitüsü .

5. Gardner, W. L., \& Martinko, M. J. (1988). Impression Management in Organizations. Journal of Management, 14(2), 321-338.

6. Giacalone, R. A., \& Rosenfeld, P. (1986). Self-Presentation and Self-Promotion in an Organizational Setting. Journal of Social Psychology, 126(3), 321.

7. Goffman, E. (1959). The presentation of self in everyday life. Garden city, New York: Doubleday Anchor.

8. Jain, Ajay K. (2012), Moderating Effect of Impression Management On the Relationship of Emotional Intelligence and Organizational Citizenship Behavior, Institute of Behavioral and Applied Management, pp.86-107

9. Jones, E. E., \& Pittman, T. S. (1982). Toward a general theory of strategic self presentation, Psychological perspectives on the Self, ed J.Suls, 1: 231-262.Hillsdale, NJ: Erlbaum.

10. Provis, Chris (2010), The ethics of impression management, Business Ethics: A European Review Volume 19 Number 2 .192-212

11. Rosenfeld, Giacalone, \& Riordan. (1995). Impression Management inOrganizations: Theory, measurement, practice: Routledge, London.

12. Rudman, L. A. (1998). Self-Promotion as a Risk Factor for Women: The Costs and Benefits of Counterstereotypical Impression Management. Journal of Personality \& Social Psychology, 74(3), 629-645.

13. Sallot T, L.M. (2002). What the public thinks about public relations: An impression management experiment. Journalism \& Mass Communication Quarterly, 79 (1), 150-164.

14. Schlenker, B. R. (1980). Impression Management: the self-concept, social identity, and interpersonal relations. Belmont, California: Wadworth, Inc.,.

15. Sharp, Mark J.; Getz, J. Greg (1998) Self-process in comorbid mental illness and drug abuse. American Journal of Orthopsychiatry, Vol 68(4), 639-644.

16. Taylor, S. E. (1997). Social psychology. New Jersey: Prentice Hall.

17. Tedeschi, J. T. (1981). Impression Management Theory and Social Psychological Research. New York: Academic press, Inc.

18. Wayne, S. J., \& Liden, R. C. (1995). Effects of impression management on performance ratings: A longitudinal study. Academy of Management Journal, 38(1), 232. 